\title{
Toxicological and morphological analysis of Africanized Apis mellifera selected for tolerance to the neonicotinoid thiamethoxam
}

\author{
Análise toxicológica e morfológica de Apis mellifera africanizadla selecionada para tolerância ao \\ neonicotinoide tiametoxam \\ Análisis toxicológica y morfológica de Apis mellifera africanizada seleccionada por tolerancia al \\ neonicotinoide tiametoxam
}

Received: 01/18/2021 | Reviewed: 01/29/2021 | Accept: 01/02/2021 | Published: 02/08/2021

\author{
William Cristian da Silva Pizzaia \\ ORCID: https://orcid.org/0000-0002-5160-2883 \\ Universidade Estadual de Maringá, Brazil \\ E-mail: wilbiologia@hotmail.com \\ Tamiris de Oliveira Diniz \\ ORCID: https://orcid.org/0000-0002-9737-9154 \\ Universidade Estadual de Maringá, Brazil \\ E-mail: tamirisc.biologicas@hotmail.com \\ Breno Gabriel da Silva \\ ORCID: https://orcid.org/0000-0002-8322-9235 \\ Universidade de São Paulo, Brazil \\ E-mail: brenogsilva@usp.br \\ Naiara Climas Pereira \\ ORCID: https://orcid.org/0000-0003-1718-0848 \\ Universidade Estadual de Maringá, Brazil \\ E-mail: naiaraclimas@gmail.com \\ Adriana Aparecida Sinópolis-Gigliolli \\ ORCID: https://orcid.org/0000-0002-2752-642X \\ Universidade Estadual de Maringá, Brasil \\ E-mail: adrianasinopolis@ hotmail.com \\ Angélica de Souza Khatlab \\ ORCID: https://orcid.org/0000-0003-4823-4327 \\ Universidade Estadual de Maringá, Brazil \\ E-mail: angelicakhatlabuem@gmail.com \\ Eliane Gasparino \\ ORCID: https://orcid.org/0000-0002-2611-9259 \\ Universidade Estadual de Maringá, Brazil \\ E-mail: gasparinoeliane@gmail.com \\ Vagner de Alencar Arnaut de Toledo \\ ORCID: https://orcid.org/0000-0003-1814-9703 \\ Universidade Estadual de Maringá, Brazil \\ E-mail: vaatoledo1975@gmail.com \\ Maria Claudia Colla Ruvolo-Takasusuki \\ ORCID: https://orcid.org/0000-0002-2028-9281 \\ Universidade Estadual de Maringá, Brazil \\ E-mail: claudia.ruvolo@gmail.com
}

\begin{abstract}
Honeybees are the insect most used for pollination purposes due to its efficient characteristics for this function, which reflects in positive aspects for both nature and man. The expansion of agriculture and the development of agrochemicals to combat pests has had negative impacts on honeybee health, causing its disappearance around the world. This research aimed to evaluate the effects of honeybee exposure to the neonicotinoid insecticide thiamethoxam on its survival rate, as well as on morphological and histological changes in the midgut of adult workers from the F4 generation of Apis mellifera queens tolerant to thiamethoxam and non-tolerant worker honeybees. After the bioassays, the midgut was removed for morphological evaluation. The results showed that F4 bees were more tolerance to thiamethoxam and exhibited less significant morphological changes when compared to the non-tolerant control group.
\end{abstract}

Keywords: Histology; Scanning electron microscopy; Toxicology. 


\section{Resumo}

A abelha melífera é o inseto mais utilizado para fins de polinização devido às suas características eficientes para esta função, o que se reflete em aspectos positivos tanto para a natureza quanto para o homem. A expansão da agricultura e o desenvolvimento de agroquímicos para combater as pragas tiveram impactos negativos na saúde das abelhas, causando seu desaparecimento em todo o mundo. Esta pesquisa teve como objetivo avaliar os efeitos da exposição das abelhas ao inseticida neonicotinoide tiametoxam sobre sua taxa de sobrevivência, bem como sobre as alterações morfológicas e histológicas do intestino médio de operárias adultas da geração F4 de Apis mellifera rainhas tolerantes ao tiametoxam e trabalhadoras não tolerantes abelhas. Após os bioensaios, o intestino médio foi removido para avaliação morfológica. Os resultados mostraram que as abelhas F4 foram mais tolerantes ao tiametoxam e exibiram alterações morfológicas menos significativas quando comparadas ao grupo controle não tolerante.
\end{abstract}

Palavras-chave: Histologia; Microscopia eletrônica de varredura; Toxicologia.

\title{
Resumen
}

Las abejas son el insecto más utilizado con fines de polinización por sus características eficientes para esta función, lo que se refleja en aspectos positivos tanto para la naturaleza como para el hombre. La expansión de la agricultura y el desarrollo de agroquímicos para combatir plagas ha tenido impactos negativos en la salud de las abejas, provocando su desaparición en todo el mundo. Esta investigación tuvo como objetivo evaluar los efectos de la exposición de las abejas melíferas al insecticida neonicotinoide tiametoxam sobre su tasa de supervivencia, así como sobre los cambios morfológicos e histológicos en el intestino medio de trabajadores adultos de la generación F4 de reinas Apis mellifera tolerantes al tiametoxam y trabajadoras no tolerantes abejas. Después de los bioensayos, se extrajo el intestino medio para evaluación morfológica. Los resultados mostraron que las abejas F4 eran más tolerantes al tiametoxam y exhibían cambios morfológicos menos significativos en comparación con el grupo de control no tolerante.

Palabras clave: Histología; Microscopía electrónica de barrido; Toxicología.

\section{Introduction}

In 1956, African honeybees (Apis mellifera scutellata) arrived in Brazil from Africa. In 1957, 26 of those colonies escaped and mated with the European subspecies Apis mellifera ligustica from Italy, Apis mellifera mellifera from Germany and Apis mellifera carnica from Austria, which already inhabited Brazil, emerging Africanized honeybees or polyhibrid honeybees (Kerr, 1967).

The Africanized population was able to adapt to the tropical climate, developing characteristics for its survival, such as temperature control, nest organization and tolerance to some diseases and pathogens (Bourgeois et al., 2016).

Bees are of great importance to the ecosystem, pollinating several species of plants, including crops, increasing production. A. mellifera is one of the best-studied species in the world, due to its significant services to the environment and its disappearance, due to factors such as deforestation, climate change and indiscriminate use of agrochemicals, is raising concern (Stein et al., 2017; Sanchez-Bayo et al., 2016; Oliveira et al., 2018).

The excessive use of agrochemicals in doses above the permitted favors the significant loss of pollinating insects, which can compromise the development of plant species and the survival of all living organisms that depend on plants for a living (Sanchez-Bayo et al., 2016; Oliveira et al., 2018; Chambers et al., 2019).

Increasing honey production and disease tolerance requires a great amount of work from those who manage the apiary, in addition to the interaction of the genetic with the environment. Knowing the responsiveness of individuals to the environment favors genetic enhancement (Zakour \& Bienefeld, 2015; Bourgeois et al., 2016; Hassett et al., 2018).

Queen exchange is a process to develop and implement breeding programs, bringing many advantages, such as faster production, allowing colony monitoring during the breeding program. For breeding programs, some characteristics are primal, such as laying capacity, diseases tolerance and longevity (Zakour \& Bienefeld, 2015; Bourgeois et al., 2016; Hassett et al., 2018).

Several factors directly affect honeybee lives, for instance, climate, since low temperatures associated with the damage promoted by agrochemicals result in serious problems, such as the nest abandonment. Low temperatures bring a restriction on the supply of food in the field, and for its survival, bees seek to adapt to the climate and its thermoregulatory 
mechanisms are activated, which expends a large amount of energy (Suryanarayanan \& Kleinman, 2013; Seitz et al., 2015).

After winter, bees forage on plants that were treated with agrochemicals, since crop production occurs particularly during summer and spring, which harms bee development, which can lead to death (Chambers et al., 2019).

The midgut is the gateway to food and the first access route for pathogens and substances that causes damage, so it is an important region for morphological research. As all substance absorption occurs in the midgut, morphological changes caused by the insecticide in this region of the digestive system can compromise other physiological and behavioral processes (Williamson et al., 2014; Tavares et al., 2015; Catae et al., 2014).

Honeybees exposed to agrochemicals may not be able to return to their colony because they do not maintain their sense of guidance and location, becoming a global problem due to the large-scale use of these products (Williamson et al., 2014; Oliveira et al., 2018).

Studying and understanding the action of these agrochemicals on bees it is essential to minimize the impact caused by exposure to insecticides, reducing the lethal and sublethal action effects on pollinators (Carreck \& Ratnieks, 2014; Williamson et al., 2014; Oliveira et al., 2018).

Mortality tests and critical electrolyte concentration (CEC) analysis showed that bees were tolerant of the agrochemical (Pizzaia et al., 2021). Currently, in the apiary, the fourth generation of bees descendant from queens tolerant to thiamethoxam (F4) are being kept. Therefore, the study aimed to evaluate the toxicity and morphological changes in the midgut of $\mathrm{F} 4$ adult A. mellifera workers tolerant to the neonicotinoid thiamethoxan.

\section{Methodology}

This quantitative research is characterized by the use of quantification, both in the collection as in the treatment of information, using statistical techniques (Richardson, 1999).

\section{Insects}

Adult A. mellifera workers were collected in commercial hives of the Experimental Farm of Iguatemi, from

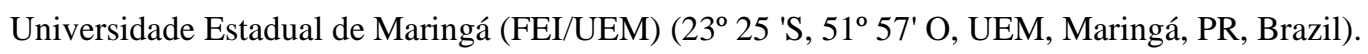

Two different types of adult A. mellifera workers were collected, first the ones from the F4 generation of queens tolerant to thiamethoxam and second honeybees without tolerance induction. Bees were kept in plastic bottles measuring $9 \times 7 \times 26 \mathrm{~cm}$, with perforations on the lids to allow air to enter. Then bees were taken to the Laboratory of Genetics Animal from the Department of Biotechnology, Genetics and Cell Biology of UEM.

\section{Bioassays}

For the bioassays, the commercial insecticide Actara 250WG (Syngenta) was diluted in water, as recommended for application on Citrus crops, producing a solution with 250 grams of active ingredient per kilogram. The final concentration used to feed the bees were $5 \times 10^{-5}$ grams of active ingredient per milliliter ( $\mathrm{g}$ a.i. $/ \mathrm{mL}$ ).

Tolerant workers were feed only with candy (bioassays 1) and feed with candy containing the agrochemical (bioassays 2). Non-tolerant workers were feed only with candy (bioassays 3) and feed with candy containing $2 \mu$ of the agrochemical (bioassays 4). The bioassays were performed with three replicates each and 20 bees per repetition for periods of 24, 48 and $72 \mathrm{~h}$. The bees were kept in glass jars for the bioassays (diameter $14.71 \mathrm{~cm} \times 18.5 \mathrm{~cm}$ tall). The glass bottles contained filter paper, a water-soaked cotton swab, and another candy container. Bees were stored in a BOD incubator, maintained in $33{ }^{\circ} \mathrm{C} \pm 2{ }^{\circ} \mathrm{C}$ and UR $80 \pm 10 \%$. After each period dead honeybees were counted. 


\section{Light microscopy}

After 24, 48 and $72 \mathrm{~h}$ of the bioassays, surviving bees where anesthetized under cold temperatures and the midgut was dissected in solution $\left(0.1 \mathrm{M} \mathrm{NaCl}, 0.1 \mathrm{M} \mathrm{Na}_{2} \mathrm{HPO}_{4}\right.$, and $\left.0.1 \mathrm{M} \mathrm{KH}_{2} \mathrm{PO}_{4}\right)$.

The midguts were fixed in aqueous Bouin's solution for $12 \mathrm{~h}$, dehydrated in an alcohol series of increasing concentrations $(70 \%, 80 \%, 90 \%$, and 100\%), diaphanized in xylene, paraffin-embedded and sectioned into $6 \mu \mathrm{m}$ slices using a microtome Leica RM 2250. Then, sections were spread on glass slides, rehydrated, and stained with hematoxylin and eosin (H/E) (Junqueira \& Junqueira, 1983). The analyses were performed under an Olympus light microscope and sections were photographed using a digital camera.

\section{Scanning electron microscopy}

After 24, 48 and $72 \mathrm{~h}$ from the beginning of the bioassays, surviving bees where anesthetized under cold temperatures and the midgut was dissected in solution $\left(0.1 \mathrm{M} \mathrm{NaCl}, 0.1 \mathrm{M} \mathrm{Na}_{2} \mathrm{HPO}_{4}\right.$, and $\left.0.1 \mathrm{M} \mathrm{KH}_{2} \mathrm{PO}_{4}\right)$.

The midguts were fixed in aqueous Bouin's solution for $12 \mathrm{~h}$, being dehydrated in an alcohol series of increasing concentrations. The samples were submitted to a critical point dry using Leica CPD 030 - BALTEC, covered by gold dust on the metallizer Shimadzu IC-50 and analyzed using the MEV QUANTA 250 of the Microscopy Center of the Complex of Research Support Centre (COMCAP) of the Universidade Estadual de Maringá/Paraná/Brazil.

\section{Data analysis}

Statistical analysis was performed using the Statistical Analysis System software (SAS, 2012). Initially, a descriptive analysis was conducted for survival bees between treatments and groups of bees. To test the effect of the treatment, the model with interaction in the main effects using variance analysis (ANOVA) - subdivided plots - was used. The Tukey test was applied to verify the multiple differences between the levels of the variables.

Treatments were divided into two groups, F4 generation and control, with three periods of time (24, 48 and $72 \mathrm{~h})$ and two types of food (with and without the agrochemical each). The results for bee survival were analyzed in a factorial scheme 2 $\mathrm{x} 3 \times 2$.

Thus, the variables survival, interactions between levels and significant interaction were analyzed through combinations between factors and the F test was used to identify significant differences. The hypothesis of normality of the error and the homogeneity of variances was evaluated by the Shapiro-Wilk test and the Bartlett test, respectively. In all tests, the level of significance was $5 \%$ significance ( $\mathrm{p}$-value $<0.05$ ).

\section{Results and Discussion}

\section{Toxicity in workers tolerant to thiamethoxan}

After oral contamination of A. mellifera with thiamethoxam, workers survival was affected, the average and median of survival levels were higher in the candy treatments, especially in the control group (Figure 1). However, the control group exposed to the agrochemical at the concentration of $5 \times 10^{-5} \mathrm{~g}$ a.i. $/ \mathrm{mL}$ showed the lowest mean and median survival levels, but also showed more variability (Figure 1a). Regarding the mean and median of survival levels between the experimental periods, the highest levels were observed after 48 and after $72 \mathrm{~h}$ higher variability was showed. 
Figure 1. Apis mellifera survival boxplot for each treatment (a) and experimental period (b).

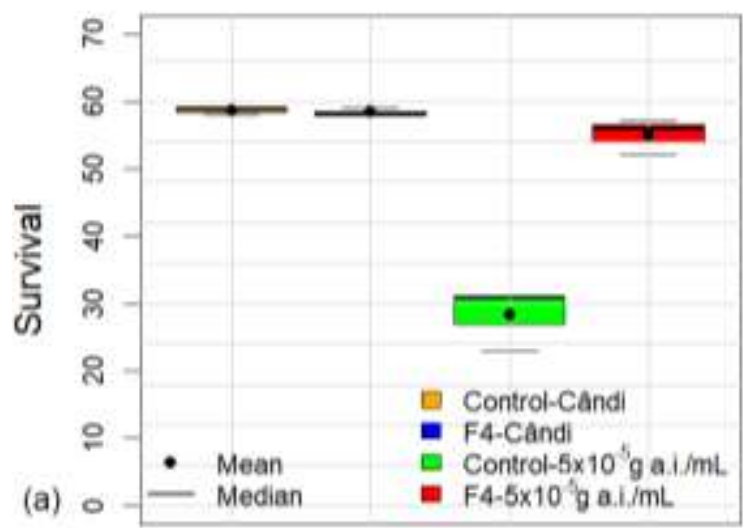

Treatments

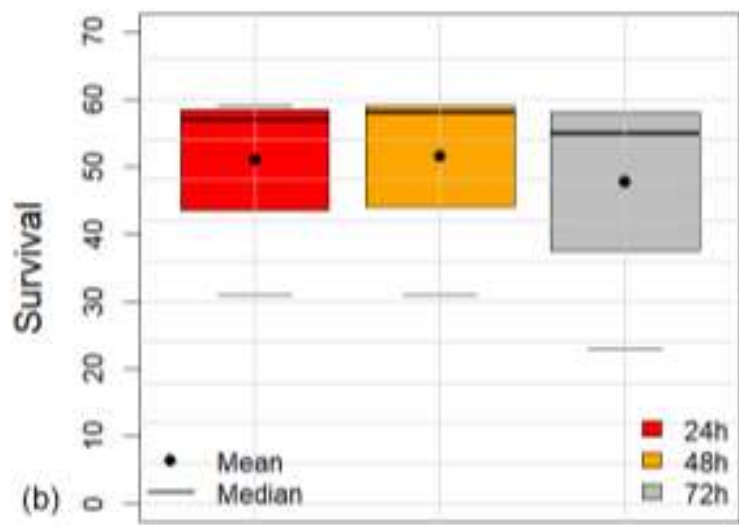

Experiment Period

Source: Authors.

For this analysis, the effect model in subdivided plots was defined by:

$Y i j k l=\mu+A i+T j+I k+(A x T) i j+(A x I) i k+(T \times I) i k+e i j k l$

where, Yijkl indicates the response variable of the design, $\mu$ is the overall mean effect of the experiment, Ai indicates the effect of the $\mathrm{i}$-th level of the honeybee groups factor, $\mathrm{Tj}$ indicates the effect of the $\mathrm{j}$-th level of the treatment factor, Ik indicates the effect of the k-th level of the insecticide factor, (A x T)ij indicates the effect of the interactions of the i-th level of the bee groups factor with the j-th level of the treatment factor, (A x I)ik indicates the effect of the interactions of the i-th level of the bee groups factor with the k-th level of the agrochemical factor, (T x I)jk indicates the effect of the interactions of the $\mathrm{j}$ th level of the treatment factor with the k-th level of the insecticide factor and eijkl indicates the residual error.

After oral contamination of tolerant A. mellifera (bees that received treatment in the field) and the workers who are not part of this group (bees that did not receive treatment in the field), at the concentration mentioned above, for the periods of 24, 48 and $72 \mathrm{~h}$, there was a significant survival level on both groups (Table 1). Regarding the percentage of explainability of the adjusted model, it presented a value of $\mathrm{R}^{2}=0.9536$, proving to be adequate for the analysis. Concerning the assumptions of errors, there was no violation of the hypothesis of normality and homogeneity of variances (p-value>0.05).

With the results observed in ANOVA, it was verified which variables related to the analyses presented a significant difference and between which factors an interaction occurred. A significant difference was observed for the variables Groups of Bees and Agrochemical and there was a significant interaction between these variables indicating that the response of the Groups of Bees factor is dependent on the Agrochemical factor (Table 1).

The results allowed to verify the significant effects of the interaction between the factors (Table 1). It was observed the effect of the Groups of Bees factor within the levels of the Agrochemical/Candy factor, F4 tolerant A. mellifera workers fed only with candy showed a survival rate of $97.22 \%$ and the control workers presented $97.77 \%$ of survival rate on in vitro tests.

Regarding the mean of tolerant workers survival fed with candy and the agrochemical, it was observed a significant survival rate of $91.66 \%$ when compared to the control group that received the same treatment (52.66\%). Comparing the survival means of bees that were fed only with candy and the bees that received food with the agrochemical, it was found that there is proximity in the results and that F4 bees were more tolerant to the agrochemical exposure. 
Table 1. Experimental design subdivided plots: Variance Analysis (ANOVA) - Survival of tolerant Apis mellifera (F4) and control by ingesting food with or without thiamethoxam.

\begin{tabular}{|c|c|c|c|c|c|}
\hline \multirow{2}{*}{ Variables } & \multirow{2}{*}{ Levels } & \multicolumn{3}{|c|}{ Summary Measures } & \multirow{2}{*}{ p-value } \\
\hline & & \multicolumn{2}{|c|}{ Mean } & Standard Deviation & \\
\hline \multirow{2}{*}{ Groups of Bees } & Control & \multicolumn{2}{|c|}{$75,22^{b}$} & 23,75 & \multirow{2}{*}{$<0,05^{*}$} \\
\hline & $\mathrm{F} 4$ & \multicolumn{2}{|c|}{$94,44^{\mathrm{a}}$} & 5,65 & \\
\hline \multirow{3}{*}{ Time } & $24 \mathrm{~h}$ & \multicolumn{2}{|c|}{$86,41^{\mathrm{a}}$} & 18,05 & \multirow{3}{*}{0,10} \\
\hline & $48 \mathrm{~h}$ & \multicolumn{2}{|c|}{$85,83^{\mathrm{a}}$} & 21,08 & \\
\hline & $72 h$ & & & 21,03 & \\
\hline \multirow{2}{*}{ Agrochemical } & Actara & & & 21,04 & \multirow{2}{*}{$<0,05^{*}$} \\
\hline & Candy & & & 30,90 & \\
\hline \multirow[b]{2}{*}{ Main Effects } & \multirow[b]{2}{*}{ Variables } & \multirow[b]{2}{*}{ Levels } & \multicolumn{2}{|c|}{ Summary Measures } & \multirow[b]{2}{*}{ p-value } \\
\hline & & & Mean & $\begin{array}{c}\text { Standard } \\
\text { Deviation }\end{array}$ & \\
\hline \multirow{6}{*}{ Groups of Bees x Time } & \multirow{4}{*}{ Control } & $24 \mathrm{~h}$ & $77,83^{\mathrm{a}}$ & 22,58 & \multirow{6}{*}{0,53} \\
\hline & & $48 \mathrm{~h}$ & $75,00^{\mathrm{a}}$ & 26,07 & \\
\hline & & $72 \mathrm{~h}$ & $72,83^{\mathrm{a}}$ & 26,72 & \\
\hline & & $24 \mathrm{~h}$ & $95,00^{\mathrm{a}}$ & 5,47 & \\
\hline & \multirow[t]{2}{*}{ F4 } & $48 \mathrm{~h}$ & $96,66^{\mathrm{a}}$ & 4,08 & \\
\hline & & $72 \mathrm{~h}$ & $91,66^{\mathrm{a}}$ & 6,83 & \\
\hline \multirow{4}{*}{ Groups of Bees x Agrochemical } & \multirow{2}{*}{ Control } & Actara & $52,66^{\mathrm{b}}$ & 6,92 & \multirow{4}{*}{$<0,05^{*}$} \\
\hline & & Candy & $97,77^{\mathrm{a}}$ & 2,63 & \\
\hline & \multirow{2}{*}{ F4 } & Actara & $91,66^{\mathrm{a}}$ & 6,12 & \\
\hline & & Candy & $97,22^{\mathrm{a}}$ & 3,63 & \\
\hline \multirow{6}{*}{ Time x Agrochemical } & \multirow{2}{*}{$24 \mathrm{~h}$} & Actara & $75,33^{\mathrm{a}}$ & 20,36 & \multirow{6}{*}{0,27} \\
\hline & & Candy & $97,50^{\mathrm{a}}$ & 2,73 & \\
\hline & $48 \mathrm{~h}$ & Actara & $73,33^{\mathrm{a}}$ & 24,42 & \\
\hline & $48 \mathrm{~h}$ & Candy & $98,33^{\mathrm{a}}$ & 2,58 & \\
\hline & \multirow{2}{*}{$72 h$} & Actara & $67,83^{\mathrm{a}}$ & 21,40 & \\
\hline & & Candy & $96,66^{\mathrm{a}}$ & 4,08 & \\
\hline
\end{tabular}

*Means in the same column with different overwritten letters are significantly different by Tukey test (p-value<0.05). Source: Authors.

However, field tests will be required to corroborate these observations. It is noteworthy that the bioassays were performed with the concentration of active ingredient of thiamethoxam indicated for cochineal pest on Citrus, therefore it is a concentration of neonicotinoid that workers usually encounter during foraging.

During bioassays, some worker behaviors were observed when fed with candy containing thiamethoxam. F4 workers and control consumed most of the candy contaminated with the agrochemical, showing that the at the concentration of $5 \times 10^{-5} \mathrm{~g}$ a.i./mL the workers did not notice the presence of the insecticide (Falco et al., 2010; Kessler et al., 2015).

Kessler et al. (2015), performed a bioassay with two sources of food, pollen and Biogluc, a type of food for $A$. mellifera and Bombus terrestris. The authors found that these two species did not avoid relevant concentrations of nectar contaminated with three of the most commonly used neonicotinoids (imidacloprid, thiamethoxam and clothianidin). Also, bees of both species prefer to eat more sucrose solutions mixed with imidacloprid or thiamethoxam than with sucrose alone. The results of this study also indicated that bees did not taste neonicotinoids and are not repelled by them.

Bees preferred solutions containing imidacloprid or thiamethoxam, although the consumption of these agrochemicals made them ingest less food in general. Furthermore, stimulation with these neonicotinoids did not cause spasmodic responses of gustatory neurons in the oral parts of bees, nor inhibited the responses of sucrose-sensitive neurons. Kessler et al. (2015) concluded that bees did not control their exposure to neonicotinoids in food, this fact implies that the treatment of flowering crops with imidacloprid or thiamethoxam poses a considerable danger to foraging bees.

Control worker bees fed with thiamethoxam-contaminated candy showed difficulties in locomotion (walking and flight), tremors and spasms, while thiamethoxam-tolerant F4 workers manifested these changes at a lower frequency. 
Contamination of A. mellifera with sublethal concentrations of thiamethoxam can reduce the life expectancy of these insects (Oliveira et al., 2014). These authors experimentally verified that in a group of bees exposed to $1 / 10$ of the thiamethoxam $\mathrm{LC}_{50}$ there was a $41.2 \%$ life expectancy reduction.

The results suggest that the tolerance to neonicotinoids can occur relatively quickly in A. mellifera, which can be harmful to bee products because forages can carry contaminated materials to the colony, which will be sold to the general public. Furthermore, we are not yet aware of the long-term consequences of this contamination for bees.

\section{Midgut morphological alterations}

The digestive tube of bees is divided into three parts, foregut, midgut and the hindgut. The A. mellifera midgut has a tubular shape and starts in the heart valve reaching the pylorus. It is surrounded by two layers of slender muscle fibers: the circular ones forming the folds of the midgut and the longitudinal ones with numerous branches, in the open weft (Snodgrass, 1956; Landim, 2009). The intestine is the organ responsible for the digestion and absorption of nutrients, being an essential region for toxicity analysis.

After 24, 48 and $72 \mathrm{~h}$ of feeding the bees only with candy, it was observed through scanning electron microscopy that the muscle fibers circular muscle fibers arranged internally and as longitudinal outermost of the outer part of the midgut showed organized musculature and without disruption (Figures $2 \mathrm{~A}-\mathrm{C}$ ).

When bees from the control group were submitted to contamination by ingestion with thiamethoxam for $24 \mathrm{~h}$ the muscle fibers, mainly the longitudinal of the midgut became even tick (Figure $2 \mathrm{D}$ ). After $48 \mathrm{~h}$ it was observed muscle fibers disorganized and deformities in the musculature (Figure $2 \mathrm{E}$ ). After $72 \mathrm{~h}$, the muscle fibers of the midgut became even tinner when compared to control (Figure $2 \mathrm{~F}$ ).

It was also observed the external musculature of the F4 worker midgut exposed only to the candy food, which presented thicker muscle fibers (Figure $3 \mathrm{~A}-\mathrm{C}$ ), when compared to the field control (Figure $2 \mathrm{~A}-\mathrm{C}$ ), probably an adaptation to contamination with neonicotinoid, because these bees are being kept in hives with contact with the agrochemical since the first generation, a process initiated five years ago (2015). After exposure for 48 and $72 \mathrm{~h}$ to the agrochemical, there was a reduction in the thickness of midgut muscle fibers (Figures $3 \mathrm{E}-\mathrm{F}$ ), resembling the musculature of the non-tolerant group (Figure 2).

All alterations observed were in response to the effect of the agrochemical thiamethoxam in which the dosage applied $\left(5 \times 10^{-5} \mathrm{~g}\right.$ a.i. $\left./ \mathrm{mL}\right)$ was extremely harmful to the insect when administered by ingestion. Since the intestinal epithelium rests on this musculature, the reduction of muscle fibers observed in longer periods of exposure in tolerant bees, as well as, in bees not tolerant to thiamethoxam, can lead to the morphological compromise of this organ, as well as cause damage to its functioning and, consequently, the survival of bees.

According to Landim (2009), the midgut epithelium is made of digestive cells supported on the basal lamina. It shows homogeneous cytoplasm, a nucleus in the middle-apical region facing the lumen, covered by microvilli (Figures 4 A-C). Digestive cells secrete enzymes related to the process of digestion and absorption (Serrão \& Landim, 2000; Cooper et al., 2009; Teixeira et al., 2013).

In the basal region of the epithelium, it was observed the presence of regenerative cells organized in regeneration nests (Figure 4 A-B) these cells are related to the replacement of the main cells (Teixeira et al., 2013). 
Research, Society and Development, v. 10, n. 2, e14310212109, 2021

(CC BY 4.0) | ISSN 2525-3409 | DOI: http://dx.doi.org/10.33448/rsd-v10i2.12109

Figure 2. Midgut scanning electron microscopy of adult Apis mellifera workers from the control group after contamination by ingestion.
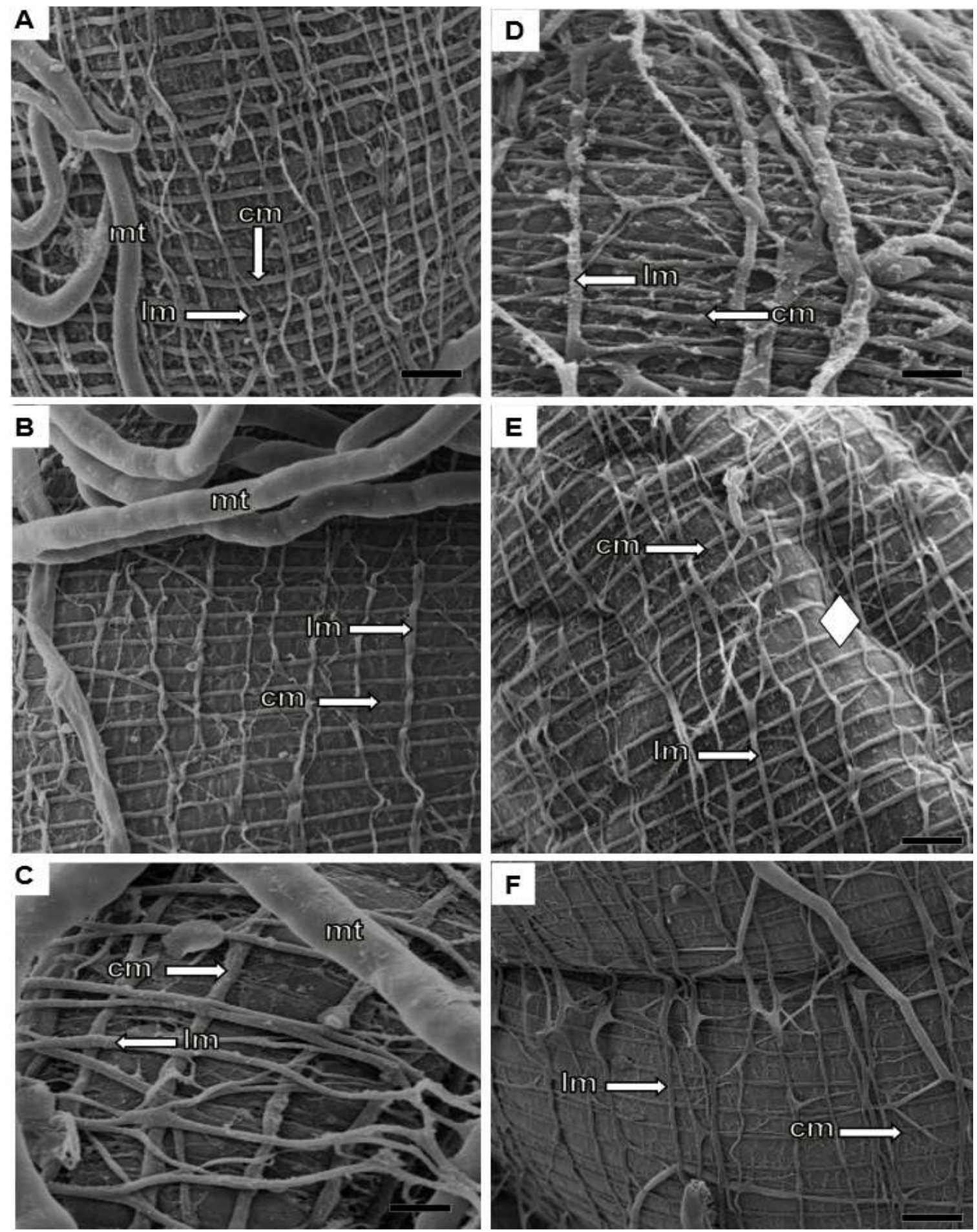

A) $24 \mathrm{~h}$ candy, B) $48 \mathrm{~h}$ candy, C) $72 \mathrm{~h}$ candy, D) $24 \mathrm{~h}$ candy + thiamethoxam, E) $48 \mathrm{~h}$ candy + thiamethoxam, F) $72 \mathrm{~h}$ candy + thiamethoxam. lm: longitudinal musculature; $\mathrm{cm}$ : circular musculature; mt: Malpighi tubules; $\diamond$ : deformation. Scale: $200 \mu \mathrm{m}, 500 \mathrm{x}$. Source: Authors. 
Research, Society and Development, v. 10, n. 2, e14310212109, 2021

(CC BY 4.0) | ISSN 2525-3409 | DOI: http://dx.doi.org/10.33448/rsd-v10i2.12109

Figure 3. Midgut scanning electron microscopy of adult Apis mellifera workers tolerant F4 after contamination by ingestion.
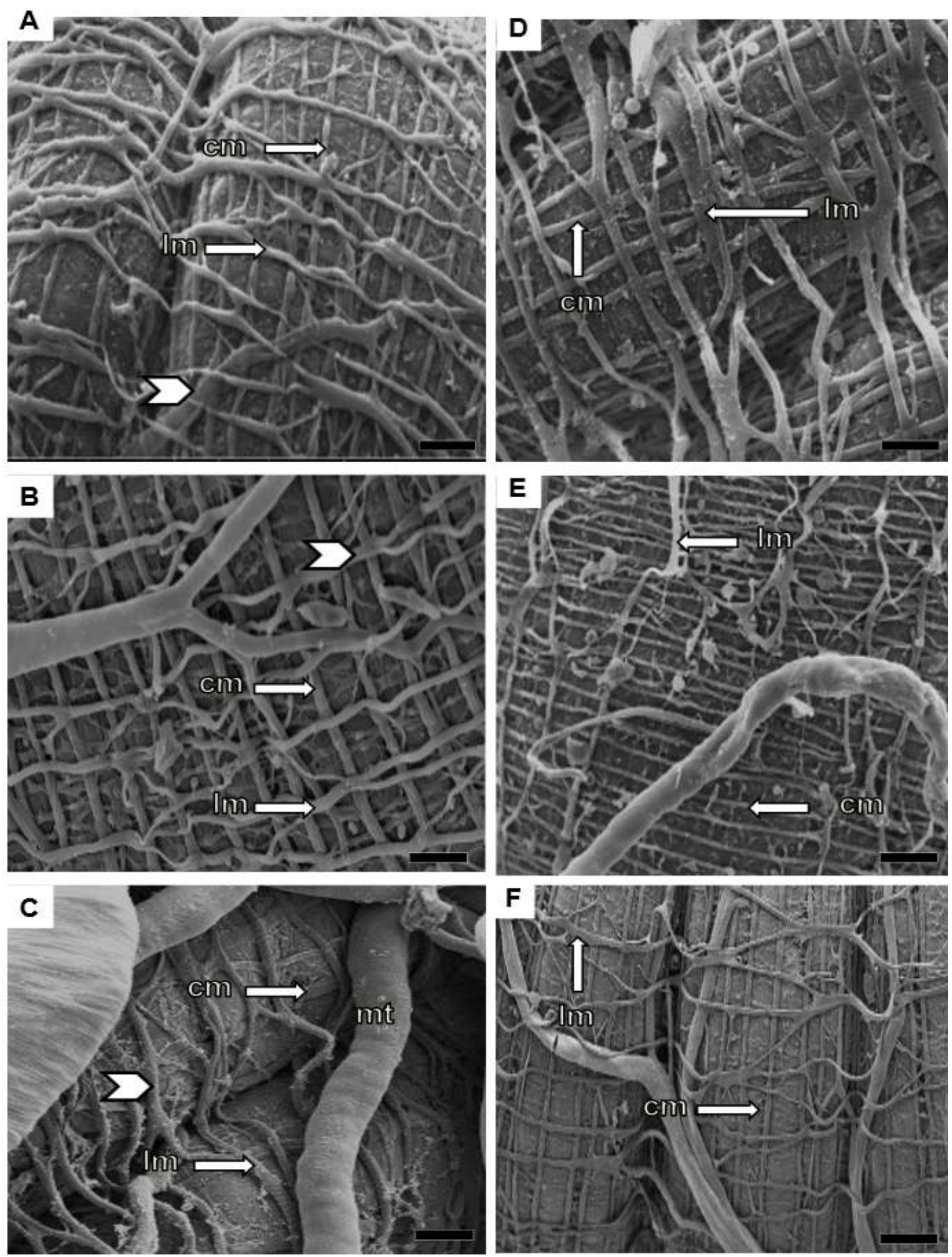

A) $24 \mathrm{~h}$ candy, Scale: $200 \mu \mathrm{m}, 500 \mathrm{X}$; B) $48 \mathrm{~h}$ candy, Scale: $100 \mu \mathrm{m}, 1000 \mathrm{X}$; C) $72 \mathrm{~h}$ candy, Scale: $100 \mu \mathrm{m}, 1000 \mathrm{X}$; D) $24 \mathrm{~h}$ candy + thiamethoxam, Scale: $200 \mu \mathrm{m}, 500 \mathrm{X}$; E) $48 \mathrm{~h}$ candy + thiamethoxam, Scale: $200 \mu \mathrm{m}, 500 \mathrm{X}$; F) $72 \mathrm{~h}$ candy + thiamethoxam, Scale: $200 \mu \mathrm{m}$, 500X. lm: longitudinal musculature; cm: circular musculature; mt: Malpighi tubules; $\square$ : thick fibers. Scale: $100 \mu \mathrm{m}$. Source: Authors.

In the lumen, the peritrophic membrane acts as a mechanical barrier (Figure $4 \mathrm{~B}-\mathrm{C}$ ). It is made with chitin and proteins called peritrophins and coats the wall of the intestinal epithelium, involving the food that passes through the light of the ventricle, moving the cells away from friction with the solid food. Thus, the peritrophic membrane consists of two compartments, an internal side called endoperitotrophic space, which is in contact with food and the outer membrane that is 
called ectoperitotrophic space and is in contact with epithelial cells (Moussian, 2013; Teixeira et al., 2013).

Figure 4. Light microscopy of adult Apis mellifera workers from the control group.

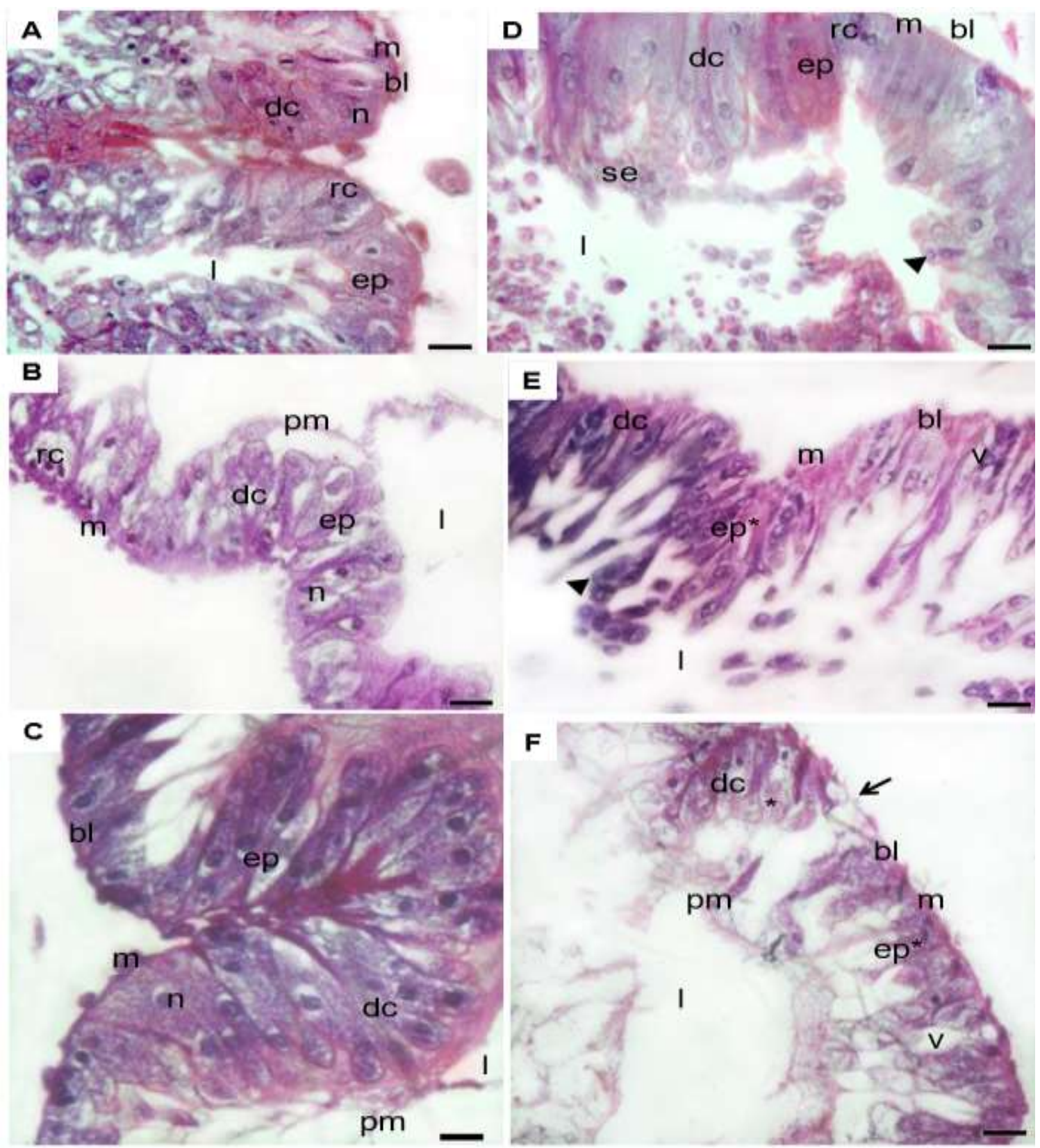

A) $24 \mathrm{~h}$ candy, B) $48 \mathrm{~h}$ candy, C) $72 \mathrm{~h}$ candy, D) $24 \mathrm{~h}$ candy + thiamethoxam, E) $48 \mathrm{~h}$ candy + thiamethoxam, F) $72 \mathrm{~h}$ candy + thiamethoxam. l: lumen; v: vacuoles; m: musculature; pm: peritrophic membrane; rc: regenerative cells; bl: basal lamina; ep: epithelium; dc: digestive cell; n: nucleus; se: secretion; 7 digestive cell loss; * : granulations; $\uparrow$ : disruption of musculature. Scale: $100 \mu \mathrm{m}, 20 \mathrm{X}$. Source:
authors.

After exposure to thiamethoxam, changes were observed in the epithelium and damage were intensified according to the exposure period (Figure 4 D-F). After 24 h, the epithelium was organized when compared to the control group, initiating the secretion and cell loss to the lumen and the regenerative cells were not in their characteristic form (Figure $4 \mathrm{D}$ ).

After $48 \mathrm{~h}$, the degenerative cells showed cytoplasm granulations and vacuoles, excessive release of these cells to the lumen and epithelium degeneration. When the midgut musculature is fragile and disrupted it ends up breaking up, consequently, the epithelium loses support which evidences epithelial destruction by the effect of the insecticide (Figures $2 \mathrm{E}-$ F, 4 F). 
Besides, the peritrophic membrane was disorganized and regenerative cells were not observed (Figure 4 E-F). The absence of these regenerative cells may indicate the attempt to be differentiated into new digestive cells to replace those that were damaged, regenerating the epithelium, in order to keep the bees alive for longer.

In F4 honeybees fed only with candy, there was organized prismatic cells with nucleus evidencing the organization of the epithelium. In its basal region, it was observed regenerative cells indicating cell activity for regeneration, with the presence of peritrophic membrane in the lumen (Figure $5 \mathrm{~A}-\mathrm{B}$ ). The musculature remained organized (Figure $4 \mathrm{~A}-\mathrm{C}$ ).

After 24, 48 e $72 \mathrm{~h}$ of contamination the F4 workers, was observed epithelial degeneration with release of digestive cells for lumen (Figures $5 \mathrm{C}-\mathrm{E}$ ) and epithelium vacuolated evident in bees after 48 and $72 \mathrm{~h}$ of exposure (Figures 5 E-F). However, the presence of peritrophic membrane, characterizing a reorganization of this structure (Figures $5 \mathrm{C}-\mathrm{E}$ ).

Figure 5. Light microscopy of adult Apis mellifera workers from the F4 group.

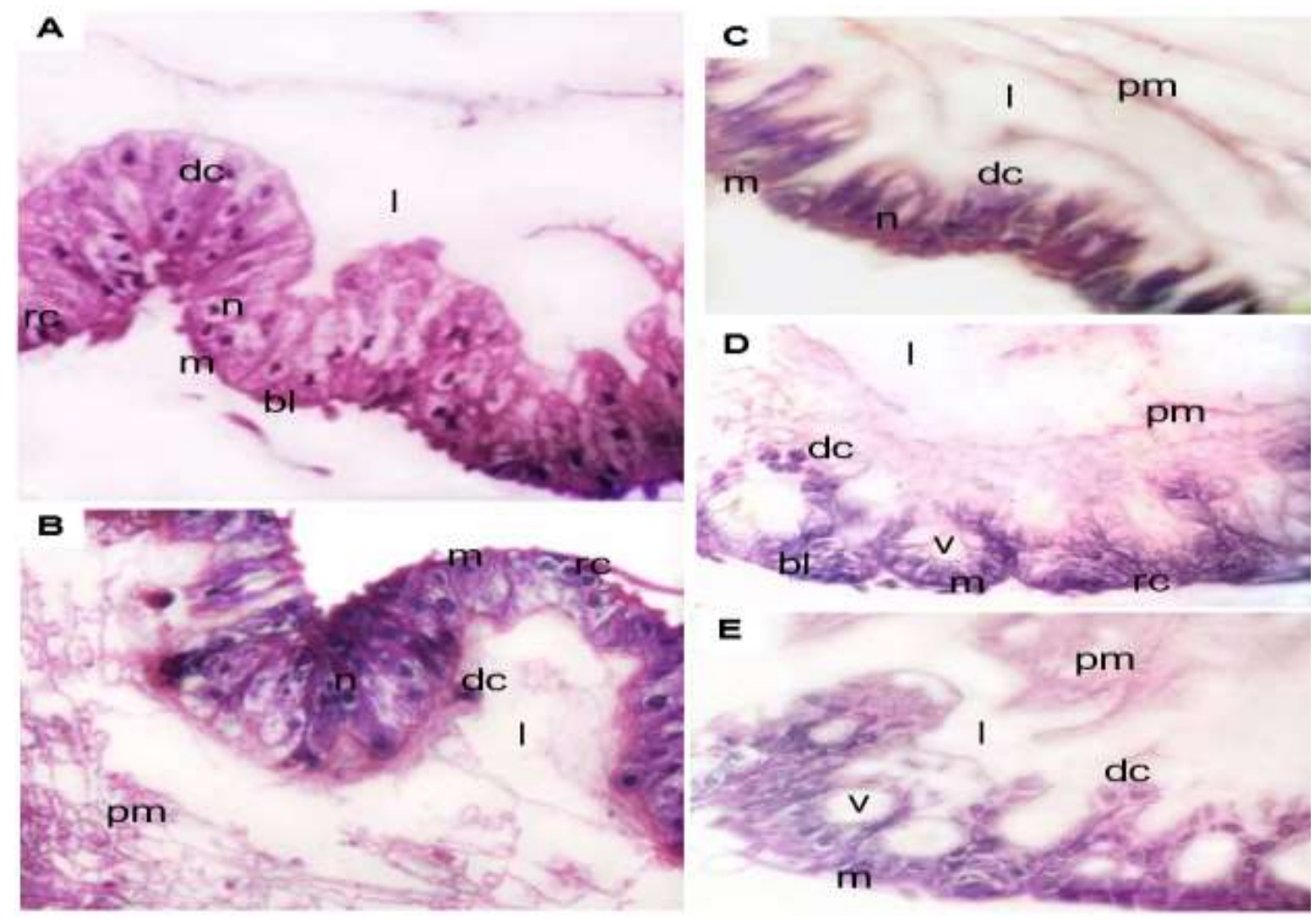

A) $48 \mathrm{~h}$ candy, B) $72 \mathrm{~h}$ candy, C) $24 \mathrm{~h}$ candy + thiamethoxam, D) $48 \mathrm{~h}$ candy + thiamethoxam, E) $72 \mathrm{~h}$ candy + thiamethoxam. 1: lumen; v: vacuoles; m: musculature; pm: peritrophic membrane; rc: regenerative cells; bl: basal lamina; dc: digestive cell; n: nucleus; se: secretion. Scale: $100 \mu \mathrm{m}, 20 \mathrm{X}$. Source: Authors.

The destructive effects of thiamethoxam were highlighted with the presence of vacuoles, muscle fragile, increased secretion, membrane rupture, which is linked to the release of digestive cells (Oliveira et al., 2014).

The effects of the agrochemical on honeybee are adverse and may affect several aspects of their life. Some responses occur through physiological and morphological changes altering musculature, epithelium and peritrophic membrane, which results in harmful behavior effects, impairing usual tasks, such as food collection, compromising colony survival for interfering with other physiological processes (Carvalho et al., 2013; Roat et al., 2013), including changes in oxygen supply, synapses, neuronal degeneration, which may explain deficiencies in learning and memory processes of bees (Catae et al., 2018).

Similar effects were identified by Diniz et al. (2020) after oral contamination of Scaptotrigona bipunctata bees with a combined insecticide containing the neonicotinoid and pyrethroid chemical groups. In this study, several morphological 
changes were observed in the midgut, such as the degradation of the peritrophic membrane, epithelium disorganization and the musculature loosening.

F4 honeybees tolerant to thiamethoxan showed significance tolerance to the agrochemical, with a higher survival rate when compared to the non-tolerant control group. Also, they responded better to contamination, when compared to honeybees that were not previously exposed to the agrochemical in the field.

\section{Conclusion}

Adult F4 A. mellifera workers showed tolerance to the neonicotinoid thiamethoxan, due to the estimated interaction with the effect of the agrochemical and survival of honeybees that contaminated by ingestion. Through scanning electron microscopy and light microscopy, morphological changes were detected in the midgut of contaminated honeybees. However, F4 tolerant bees showed less significant changes and a faster recovery in the internal morphology of the midgut after $72 \mathrm{~h}$ of thiamethoxan contamination.

\section{References}

Bourgeois, A. L., Rinderer, T. E., Guzman, L. I., \& Holloway, B. (2016). Molecular genetic analysis of Varroa destructor mites in brood, fallen injured mites, and worker bee longevity in honey bees. Journal of Apicultural Research, 54 (4), 1-7. 10.1080/00218839.2016.1160635

Carreck, N. L., \& Ratnieks, F. L. W. (2014). The dose makes the poison: have "field realistic" rates of exposure of bees to neonicotinoid insecticides been overestimated in laboratory studies? Journal of Apicultural Research, 53 (5), 607-617. 10.3896/IBRA.1.53.5.08

Carvalho, S. M., Belzunces, L. P., Carvalho, G. A., Brunet, J. L., \& Badiou-Beneteau, A. (2013). Enzymatic biomarkers as tools to assess environmental quality: a case study of exposure of the honey bee Apis mellifera to insecticides. Environmental Toxicology Chemistry, 32 (9), 2117-2124. 10.1002/etc.2288

Catae, A. F., Roat, T. C., Oliveira, R. A., Nocelli, R. C. F., \& Malaspina, O. (2014). Cytotoxic effects of thiamethoxam in the midgut and malpighian tubules of Africanized Apis mellifera (Hymenoptera: Apidae). Microscopy Research \& Technique, 77 (4), 274-281. 10.1002/jemt.22339

Catae, A. F., Roat, T. C., Pratavieira, M., Silva-Menegasso, A. R., Palma, M. S., \& Malaspina, O. (2018). Exposure to a sublethal concentration of imidacloprid and the side effects on target and nontarget organs of Apis mellifera (Apidae). Ecotoxicology, 27 (2), 109-121. 10.1007/s10646-017-1874-4

Chambers, R. G., Chatzimichael, K., \& Tzouvelekas, V. (2019). Sub-lethal concentrations of neonicotinoid insecticides at the field level affect negatively honey yield: Evidence from a 6-year survey of Greek apiaries. PLOS ONE, 14 (4), e0215363. 10.1371/journal.pone.0215363

Cooper, D. M., Granville, D., \& Lowenberger, C. (2009). The insect caspases. Apoptosis, 14 (3), 247-256. 10.1007/s10495-009-0322-1

Diniz, T. O., Pereira, N. C., Silva, B. G., Pizzaia, W. C. S., Oliveira, F. G. M., Sinópolis-Gigliolli, A. A., \& Ruvolo-Takasusuki, M. C. C. (2020). Toxicity and effects of combined agrochemical in Scaptotrigona bipunctata bees. Scientific Electronic Archives, 13 (12), 41-53. 10.36560/131220201258

Falco, J. R. P., Hashimoto, J. H., Fermino, F., \& Toledo, V. A. A. (2010). Toxicity of thiamethoxam, behavioral effects and alterations in chromatin of Apis

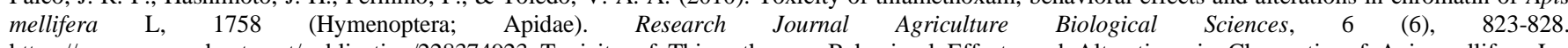
https://www.researchgate.net/publication/228374923_Toxicity_of_Thiamethoxam_Behavioral_Effects_and_Alterations_in_Chromatin_of_Apis_mellifera_L_ 1758_Hymenoptera_Apidae

Hassett, J., Browne, K., McCormack, G. P., Soland, G., \& Geary, M. (2018). A significant pure population of the dark European honey bee (Apis mellifera mellifera) remains in Ireland. Journal of Apicultural Research, 57 (3), 337-350. 10.1080/00218839.2018.1433949

Junqueira, L. C. U \& Junqueira, L. M. M. S. (1983). Basic Techniques of Cell Biology. São Paulo, Brazil: Santos.

Kerr, W. E. (1967) The history of introduction of African bees to Brazil. South African Bee Journal, 39 (1), 3-5. https://www.scienceopen.com/document?vid=7f97a3c7-3e22-4056-a99d-0d60f42504f3

Kessler, S. C., Tiedeken, E. J., Simcock, K. L., Derveau, S., Mitchell, J., Softley, S., Radcliffe, A., Stout, J. C., \& Wright, G. (2015). Bees prefer foods containing neonicotinoid pesticides. Nature, 10 (4), 74-76. 10.1038/nature14414

Landim, C. C. (2009). Abelhas - Morfologia e função de sistemas. Editora UNESP, 408p.

Moussian, B. (2013). The apical plasma membrane of chitin-synthesizing epithelial. Insect Science, 20 (2), 139-146. 10.1111/j.1744-7917.2012.01549.x

Oliveira, A. C., Junqueira, C. N., \& Augusto, S. C. (2018). Pesticides affect pollinator abundance and productivity of sunflower (Helianthus annuus L.). Journal of Apicultural Research, 58 (1), 2-8. 10.1080/00218839.2018.1494441

Oliveira, R. A., Roat, T. C., Carvalho, S. M., \& Malaspina, O. (2014). Side-effects of thiamethoxam on the brain and midgut of the africanized honeybee Apis mellifera (Hymenopptera: Apidae). Environmental Toxicology, 29 (10), 1122-1133. 10.1002 / tox.21842 
Research, Society and Development, v. 10, n. 2, e14310212109, 2021

(CC BY 4.0) | ISSN 2525-3409 | DOI: http://dx.doi.org/10.33448/rsd-v10i2.12109

Pizzaia, W. C. S., Pereira, N. C., Diniz, T. O., Toledo, V. A. A., \& Ruvolo-Takasusuki, M. C. C. (2021) Apis mellifera africanized queens tolerant to the neonicotinoid thiamethoxam. Scientific Electronic Archives, 14 (2), 35-42. 10.36560/14220211292

Richardson, R. J. (1999) Pesquisa social: métodos e técnicas. Atlas.

Roat, T. C., Carvalho, S. M., Nocelli, R. C. F., Silva-Zacarin, E. C. M., Oalma, M. S., \& Malaspina, O. (2013). Effects of sublethal dose of fipronil on neuron metabolic activity of Africanized honeybees. Archives of Environmental Contamination and Toxicology, 64 (3), 456-466. 10.1007/s00244-012-9849-1

Sanchez-Bayo, F., Goulson, D., Pennacchio, F., Nazzi, F., Goka, K., \& Desneux, N. (2016). Are bee diseases linked to pesticides? A brief review. Environment International, 89 (1), 7-11. 10.1016/j.envint.2016.01.009

Seitz, N., Traynor, K. S., Rennich, K., Wilson, M. E., Ellis, J. D., Rose, R., Tarpy, D., Sagili, R. R., Caron, D. M., Delaplane, K. S., Rangel, J., Lee, K., Baylis, K., Wilkes, J. T., Skinner, J. A., Petts, J. S., \& VanEngelsdorp, D. (2015). A national survey of managed honey bee 2014-2015 annual colony losses in the USA. Journal of Apicultural Research, 54 (4), 292-304. 10.1080/00218839.2016.1153294

Serrão, J. E. \& Landim, C. C. (2000). Ultrastructure of the midgut epithelium of Meliponinae larvae with different developmental stages and diets. Journal Apicultural, 39 (1), 9-17. 10.1080/00218839.2000.11101016

Snodgrass, R. E. (1956). Anatomy and physiology of the honeybees. Comstock Publishing Associates.

Stein, K., Coulibaly, D., Stenchly, K., Goetze, D., Porembski, S., Lindner, A., Konaté, S., \& Linsenmair, E. K. (2017). Bee pollination increases yield quantity and quality of cash crops in Burkina Faso, West Africa. Scientific Reports, 7 (1), 17691. 10.1038/s41598-017-17970-2

Suryanarayanan, S. \& Kleinman, D. L. (2013). Be(e)coming experts: The controversy over insecticides in the honey bee colony collapse disorder. Social Studies of Science, 43 (2), 215-240. 10.1177/0306312712466186

Tavares, D. A., Roat, T. C., Carvalho, S. M., Silva-Zacarin, E. C. M., \& Malaspina, O. (2015). In vitro effects of thiamethoxam on larvae of Africanized honey bee Apis mellifera (Hymenoptera: Apidae). Chemosphere, 135 (5), 370-378. 10.1016/j.chemosphere.2015.04.090

Teixeira, A. D., Fialho, M. C. Q., Zanuncio, J. C., Ramalho, F; S., \& Serrão, J. E. (2013). Degeneration and cell regeneration in the midgut of Podisus nigrispinus (Heteroptera: Pentatomidae) during post-embryonic development. Arthropod Structure Development, 42 (3), 237-246. 10.1016/j.asd.2013.02.004

Williamson, S. M., Willis, S. J., \& Wright, G. A. (2014). Exposure to neonicotinoids influences the motor function of adult worker honeybees. Ecotoxicology, 23 (8), 1409-1418. 10.1007/s10646-014-1283-x

Zakour, M. K., \& Bienefeld, K. (2015). Basic considerations in the development of breeding plans for honey bees, illustrated by data on the native Syrian honey bee (Apis mellifera syriaca). Journal of Apicultural Research, 53 (2), 314-326. 10.3896/IBRA.1.53.2.13 